\title{
Description of Shewanella glacialipiscicola sp. nov. and Shewanella algidipiscicola sp. nov., isolated from marine fish of the Danish Baltic Sea, and proposal that Shewanella affinis is a later heterotypic synonym of Shewanella colwelliana
}

Correspondence Masataka Satomi msatomi@affrc.go.jp

\author{
Masataka Satomi, ${ }^{1}$ Birte Fonnesbech Vogel, ${ }^{2}$ Kasthuri Venkateswaran $^{3}$ \\ and Lone Gram²
}
${ }^{1}$ National Research Institute of Fisheries Science, Fisheries Research Agency, 2-12-4 Fukuura, Kanazawa-ku, Yokohama 236-8648, Japan
${ }^{2}$ Danish Institute for Fisheries Research, Department of Seafood Research, Søltofts Plads, c/o Technical University of Denmark, Bldg 221, DK-2800 Kgs Lyngby, Denmark
${ }^{3}$ California Institute of Technology, Jet Propulsion Laboratory, Biotechnology and Planetary Protection Group, 89-2 Oak Grove Drive, Pasadena, CA 91109, USA

The majority of marine fish and seafood spoilage bacteria are reported to be members of the genus Shewanella (Shewan et al., 1960; Okuzumi et al., 1981; Gram et al., 1987;

\section{Abbreviation: TMAO, trimethylamine oxide.}

The GenBank/EMBL/DDBJ accession numbers for the 16S rRNA gene and gyrB sequences of six of the new isolates are AB205568$A B 205571, A B 205574$ and AB205577 (16S rRNA gene) and AB266200-AB266205 ( $g y r B$ ), as indicated in Figs 1 and 2.

Details of strains and DNA-DNA hybridization results are available as supplementary material in IJSEM Online.
Stenstrom \& Molin, 1990; Gram \& Huss, 1996; Vogel et al., 1997, 2005). Most Shewanella species, particularly Shewanella putrefaciens and close relatives, are capable of reducing trimethylamine oxide (TMAO) to trimethylamine and producing hydrogen sulfide $\left(\mathrm{H}_{2} \mathrm{~S}\right)$, both of which are main components of the fishy odour present during lowtemperature storage. Recently, it was reported that Shewanella baltica rather than $S$. putrefaciens is the dominant spoilage species producing $\mathrm{H}_{2} \mathrm{~S}$ in iced storage of marine fish caught in the Danish Baltic Sea (Vogel et al., 2005). Initial microbial diversity analysis of the bacterial 
populations present on these fish resulted in the classification of several strains as belonging to the genus Shewanella based on biochemical characteristics (Vogel et al., 2005) and resulted in the description of two novel species (Satomi et al., 2006) based on molecular taxonomy. Furthermore, several of the closely related Shewanella isolates were physiologically and phylogenetically so distinct that they required further taxonomic analysis (Vogel et al., 2005). Such study will help to understand the microbial species diversity of marine fish and aid in developing countermeasures for fish spoilage. Two groups of $\mathrm{H}_{2} \mathrm{~S}$-producing organisms are described herein using a polyphasic taxonomic approach that includes phenotypic characterization, phylogenetic analysis of $16 \mathrm{~S}$ rRNA and $g y r B$ genes and DNA-DNA hybridization.

A total of 40 strains of novel $\mathrm{H}_{2} \mathrm{~S}$-producing bacteria were isolated from cod and plaice caught between August 1995 and September 2001 from the Baltic Sea off Denmark. Bacterial isolation was carried out as reported by Vogel et al. (2005). Briefly, tissue samples were taken from the belly flap area of iced fish, homogenized, serially diluted in sterile peptone saline and pour-plated in iron agar (Oxoid CM964). Plates were then incubated at $25^{\circ} \mathrm{C}$ for 3 days and black colonies, indicative of $\mathrm{H}_{2} \mathrm{~S}$-producing bacteria, were picked, purified and stored for further characterization. Of 40 strains tested for phenotypic analysis, representative strains were selected for molecular taxonomy to determine their phylogenetic affiliation. The bacterial strains analysed in detail in this study are shown in Supplementary Table S1, available in IJSEM Online. In addition to these newly described strains, type strains of closely related species were purchased from several established culture collections and were used as reference strains. All isolates were maintained in trypticase soy agar (TSA; Becton Dickinson) stabs at room temperature for short-term analysis and in a medium containing skimmed-milk powder and glycerol at $-80{ }^{\circ} \mathrm{C}$ for long-term storage. Liquid cultures were grown in trypticase soy broth (TSB; Becton Dickinson) incubated at $25^{\circ} \mathrm{C}$ for 2-7 days. Representative strains have been deposited in the BCCM/LMG Bacteria Collection, Laboratorium voor Microbiologie, University of Ghent, Ghent, Belgium (LMG), and the National Institute of Technology and Evaluation, Biological Resource Center (NBRC), Japan (Supplementary Table S1).

All strains were tested at $25^{\circ} \mathrm{C}$ for the following key characteristics: Gram reaction (Gregerson, 1978), motility and cell shape [phase-contrast microscopy after growth in veal infusion broth (Difco), for $24 \mathrm{~h}$ ], cytochrome oxidase (BBL DrySlide oxidase; Becton Dickinson), catalase reaction $\left(3 \% \mathrm{H}_{2} \mathrm{O}_{2}\right)$, reduction of TMAO in TMAO medium (Gram et al., 1987) and production of $\mathrm{H}_{2} \mathrm{~S}$ from thiosulfate (Gram et al., 1987). Fermentation of glucose was tested in O-F medium (Merck) at $25^{\circ} \mathrm{C}$. Growth at various temperatures $\left(4,37\right.$ and $\left.42^{\circ} \mathrm{C}\right)$ and in $6 \% \mathrm{NaCl}$ (Vogel et al., 1997) and assimilation of several carbon and energy sources, citrate, gluconate, glucose, lactate and sucrose (Ziemke et al., 1998), were used to differentiate the Shewanella isolates further.
API 20NE kits (bioMérieux) were also employed for assimilation tests according to the manufacturer's instructions. Type strains of S. putrefaciens, Shewanella affinis, S. baltica, Shewanella colwelliana, Shewanella hafniensis and Shewanella morhuae were included in each trial and served as controls. The genomic $\mathrm{G}+\mathrm{C}$ content was determined by HPLC (Vogel et al., 1997). The ability to degrade gelatin (Frazier, 1926), DNA (Difco DNase test agar with methyl green) and ornithine (Difco) was also tested.

All of the new isolates were Gram-negative, motile rods, with positive oxidase and catalase reactions. They were unable to ferment glucose or produce indole but reduced nitrate and TMAO and produced $\mathrm{H}_{2} \mathrm{~S}$. Based on these traits, the strains were tentatively classified as members of the genus Shewanella according to established procedures (Stenstrom \& Molin, 1990). However, these characteristics were not sufficient to allow for a complete identification at the species level among the psychrotolerant shewanellae (Ziemke et al., 1997). Under optimum conditions, cells of these new isolates were $0.5-0.7 \mu \mathrm{m}$ in diameter and $1.0-1.2 \mu \mathrm{m}$ long. Colonies were round, undulate, beige and non-luminescent and had irregular margins on TSA plates incubated at $25^{\circ} \mathrm{C}$ for 1 day. All strains were able to grow between 4 and $30^{\circ} \mathrm{C}$.

The first group (group 1; group C5 of Vogel et al., 2005) was composed of seven strains, including strain $\mathrm{T} 147^{\mathrm{T}}$, and showed similar phenotypic traits to psychrotolerant $S$. morhuae strains, but differed from S. morhuae in that they assimilated lactate (Table 1). These strains were also distinguished from S. putrefaciens, S. baltica and S. hafniensis by their carbohydrate assimilation patterns, ability to grow at $37^{\circ} \mathrm{C}$ and production of gelatinase. Furthermore, the $\mathrm{G}+\mathrm{C}$ content of these strains was $44 \mathrm{~mol} \%$, which differs from that of S. putrefaciens, S. baltica and S. hafniensis. These results suggest that group 1 was phenotypically similar to, but nevertheless distinguishable from, known authentic Shewanella species. A second group (group 2; groups $\mathrm{C} 1$ and C2 of Vogel et al., 2005) encompassing 33 strains and represented by strain $S 13^{\mathrm{T}}$ grew well at $4{ }^{\circ} \mathrm{C}$, but assimilated only three of the carbohydrates tested (Table 1). This group was phenotypically different from $S$. colwelliana ATCC $39565^{\mathrm{T}}$ and S. affinis ATCC BAA- $642^{\mathrm{T}}$, which were phylogenetically closest to the new isolates based on $16 \mathrm{~S}$ rRNA gene sequence analysis (Vogel et al., 2005). Strains of group 2 grew in $6 \% \mathrm{NaCl}$ but did not degrade DNA or ornithine. The $\mathrm{G}+\mathrm{C}$ content was $47 \mathrm{~mol} \%$, indicating that they were different from $S$. colwelliana $(46 \mathrm{~mol} \%)$ and $S$. affinis (45 mol\%). Although the phenotypic traits of group 2 strains were somewhat similar to those of S. putrefaciens, they showed a number of phenotypic differences (Table 1): they liquefied gelatin and grew in $6 \% \mathrm{NaCl}$, arabinose was not utilized as a sole carbon source and they did not produce DNase or ornithine decarboxylase.

The $16 \mathrm{~S}$ rRNA and $g y r B$ genes were amplified by PCR with universal primer sets as described by Weisburg et al. (1991) and Yamamoto \& Harayama (1995) and subsequently sequenced. To extract DNA, cells were cultured in TSB and 
Table 1. Phenotypic characteristics of the new isolates and the type strains of Shewanella species

Strains: 1, Shewanella sp. T147 ${ }^{\mathrm{T}}$ group (seven strains); 2, S. morhuae ATCC BAA-1205 ${ }^{\mathrm{T}}$; 3, S. hafniensis ATCC BAA-1207 ${ }^{\mathrm{T}}$; 4, S. putrefaciens ATCC $8071^{\mathrm{T}}$; 5, S. baltica NCTC $10335^{\mathrm{T}}$; 6, Shewanella sp. S13 ${ }^{\mathrm{T}}$ group (33 strains); 7, S. affinis ATCC BAA-642 ${ }^{\mathrm{T}}$; 8, S. colwelliana ATCC $39565^{\mathrm{T}}$. All strains are Gram-negative, rod-shaped, motile and produce $\mathrm{H}_{2} \mathrm{~S}$. All strains are positive for cytochrome oxidase and catalase, hydrolyse aesculin, reduce TMAO and reduce nitrate to nitrite. All strains are non-fermentative, do not produce arginine dihydrolase, $\beta$ galactosidase or indole and do not hydrolyse urea. None of the strains grows at $42{ }^{\circ} \mathrm{C}$ or assimilates mannose, mannitol, adipic acid or phenylacetic acid. For the new isolates, numbers refer to percentages of strains that are positive.

\begin{tabular}{|c|c|c|c|c|c|c|c|c|c|}
\hline Characteristic & Reference/medium/ID kit & 1 & 2 & 3 & 4 & 5 & 6 & 7 & 8 \\
\hline \multicolumn{10}{|l|}{ Growth at: } \\
\hline $37^{\circ} \mathrm{C}$ & $50 \%$ marine agar & 0 & - & - & + & - & 70 & - & - \\
\hline Growth in $6 \% \mathrm{NaCl}$ & Vogel et al. (1997) & 0 & - & + & - & + & 100 & + & - \\
\hline Gelatinase & Gelatin agar & 100 & + & + & + & + & 0 & + & + \\
\hline Ornithine decarboxylase & Decarboxylase agar & 100 & + & + & + & + & 0 & + & + \\
\hline \multicolumn{10}{|l|}{ Assimilation of: } \\
\hline Lactate & Vogel et al. (2005) & 100 & - & + & + & + & 100 & - & - \\
\hline Sucrose & Vogel et al. (2005) & 0 & - & - & - & + & 0 & - & - \\
\hline Gluconate & API 20NE & 100 & + & + & - & + & 0 & - & + \\
\hline Capric acid & API 20NE & 0 & - & + & - & + & 3 & - & - \\
\hline Malate & API 20NE & 100 & + & + & + & + & 100 & - & - \\
\hline Citrate & API 20NE & 0 & - & + & - & + & 0 & - & - \\
\hline
\end{tabular}

collected by centrifugation. Cell pellets were suspended in TE buffer ( $\mathrm{pH}$ 8.0) and treated with SDS (final concentration $5 \mathrm{mg} \mathrm{ml}^{-1}$ ) for lysis. Extraction of chromosomal DNA and subsequent purification steps were carried out according to standard methods (Johnson, 1981; Sambrook et al., 1989). The identity of a given PCR product was verified by bidirectional sequencing analysis. The phylogenetic relationships of organisms covered in this study were determined by comparison of individual 16S rRNA gene or gyrB sequences with existing sequences in public databases using the BLAST algorithm (Altschul et al., 1990). The multiple alignment calculation of nucleotide substitution rates ( $K_{\text {nuc }}$ values; Kimura, 1980 ) and the construction of phylogenetic trees by the neighbour-joining method (Saitou $\&$ Nei, 1987) were performed using the CLUSTAL W program (Thompson et al., 1994). Alignment gaps, primer regions for PCR amplification and unidentified base positions were not taken into consideration for the calculations. The topological robustness of the phylogenetic trees was evaluated by a bootstrap analysis through 1000 replications.

Approximately $1.4 \mathrm{kbp}$ nucleotide sequences of $16 \mathrm{~S}$ rRNA genes and $1.1 \mathrm{kbp}$ nucleotide sequences of the $g y r B$ genes were used for phylogenetic analyses. A phylogenetic tree based on the 16S rRNA gene (Fig. 1) indicated that the new isolates clustered with members of the genus Shewanella. Based on 16S rRNA gene sequences, the nearest neighbour of the group $1\left(\mathrm{~T} 147^{\mathrm{T}}\right)$ strains was $S$. morhuae ATCC BAA$1205^{\mathrm{T}}$, with sequence similarity of $99.9 \%$. The sequences of the group $2\left(\mathrm{~S}_{13} 3^{\mathrm{T}}\right)$ strains shared more than $99 \%$ similarity with S. colwelliana ATCC $39565^{\mathrm{T}}(99.4 \%)$ and S. affinis ATCC BAA- $642^{\mathrm{T}}(99.6 \%)$. In the case of the genus Shewanella, Venkateswaran et al. (1999) and Satomi et al. (2003) have reported that analysis of $g y r B$ sequences is useful, since the resolution of the $16 \mathrm{~S}$ rRNA gene sequence is insufficient to evaluate their phylogenetic position. Fig. 2 shows the phylogenetic tree constructed based on gyrB sequences. The group 1 strains clustered with S. morhuae, sharing $95.6 \%$ sequence similarity, and the group 2 strains were positioned monophyletically, apart from both $S$. affinis $(85.6 \%)$ and S. colwelliana (85.6\%), clearly delineating them as a distinct species. The $g y r B$ sequences of $S$. affinis and $S$. colwelliana were almost identical; there is only one base difference, and the deduced amino acid sequences were identical between the two type strains, indicating that they were probably members of the same species. The taxonomic status of the group 1 strains was still unresolved, since they shared 99.2 and $95.6 \%$ similarity with S. morhuae based on $16 \mathrm{~S}$ rRNA gene and gyrB sequences, respectively. Such similarity values are not sufficient to distinguish closely related species according to established procedures (Stackebrandt \& Goebel, 1994; Satomi et al., 2003; Venkateswaran et al., 1999). Therefore, DNA-DNA hybridization was carried out to confirm the novelty of these isolates. 


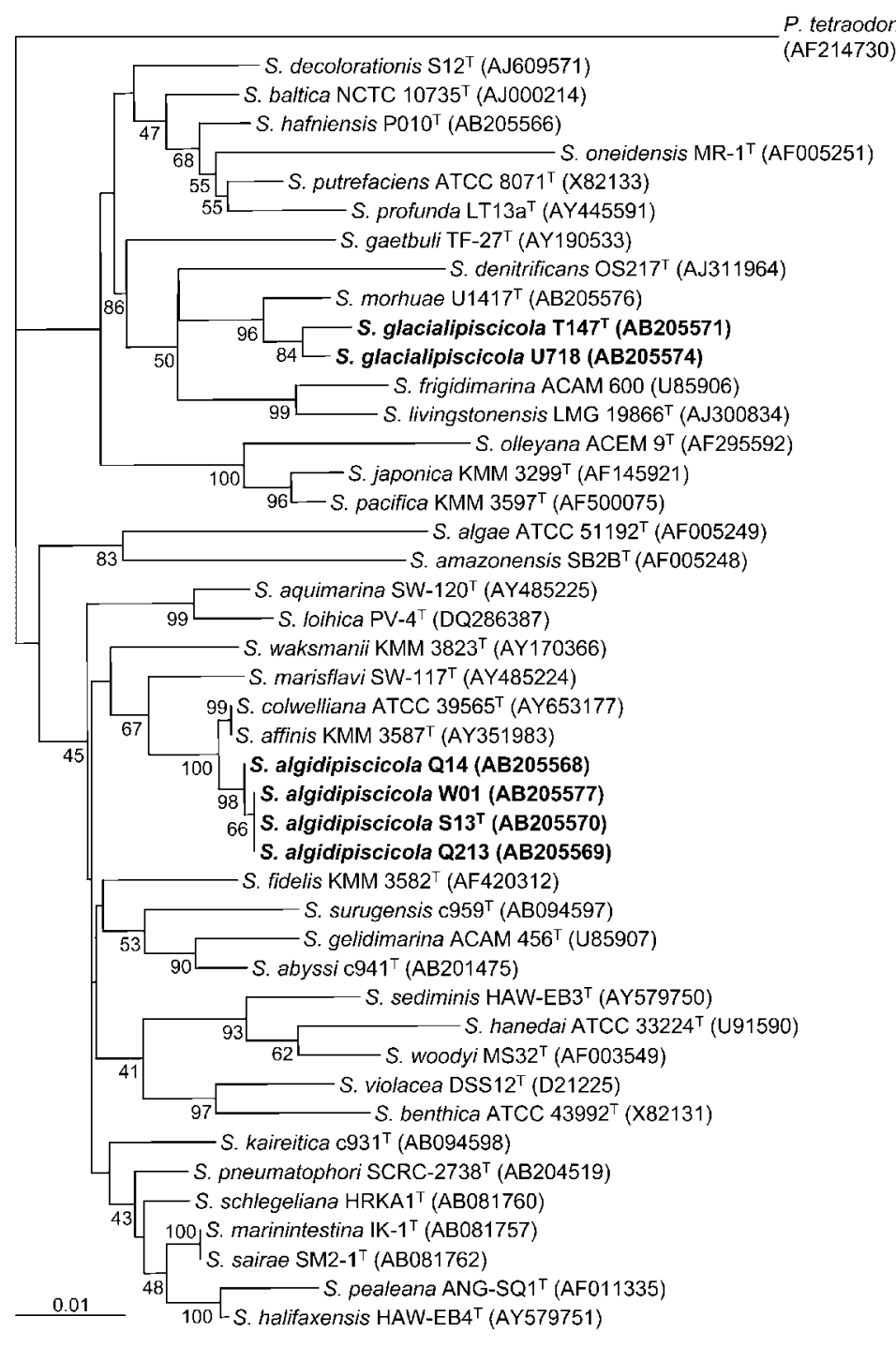

Fig. 1. Phylogenetic tree of the genus Shewanella based on 16S rRNA gene sequences. The tree was constructed using the neighbour-joining method and genetic distances were computed by Kimura's model. The scale bar indicates a genetic distance of 0.01 . Numbers at nodes indicate percentages of occurrence in 1000 bootstrapped trees; only values greater than $40 \%$ are shown. Pseudoalteromonas tetraodonis IAM $14160^{\top}$ was included as an outgroup. GenBank accession numbers are given in parentheses.

DNA-DNA hybridization was performed by microplate hybridization methods (Ezaki et al., 1989) with photobiotin labelling and colorimetric detection, using 1,2-phenylenediamine (Sigma) as the substrate and streptavidin-peroxidase conjugate (Boehringer Mannheim) as the colorimetric substrate (Satomi et al., 1997). Supplementary Table S2 shows the results of DNA-DNA hybridization between strains $\mathrm{T}_{147} 7^{\mathrm{T}}$ and $\mathrm{S} 13^{\mathrm{T}}$ and the type strains of closely related Shewanella species. Within each of the groups themselves, DNA relatedness values were significantly higher, with the group 1 and group 2 strains exhibiting relatedness values of 85 and 81-91 \%, respectively. Strains T147 ${ }^{\mathrm{T}}$ and U718 showed DNADNA hybridization values of 53-57\% with $S$. morhuae strains and less than $22 \%$ with S. putrefaciens ATCC $8071^{\mathrm{T}}$ and $S$. baltica NCTC $10735^{\mathrm{T}}$. Similarly, the group 2 strains exhibited $\sim 24$ and $\sim 28 \%$ DNA relatedness with S. affinis ATCC BAA$642^{\mathrm{T}}$ and S. colwelliana ATCC $39565^{\mathrm{T}}$, respectively. The DNADNA hybridization results strongly support the claim that isolates of group $1\left(\mathrm{~T} 147^{\mathrm{T}}\right)$ and group $2\left(\mathrm{~S} 13^{\mathrm{T}}\right)$ represent novel species within the genus Shewanella (Wayne et al., 1987).
Interestingly, S. affinis ATCC BAA $-642^{\mathrm{T}}$ and S. colwelliana ATCC $39565^{\mathrm{T}}$ had a DNA-DNA hybridization value of $76-83 \%$. This supported the results of gyrB and 16S rRNA gene sequence analysis, though some phenotypic differences exist between the two strains, such as growth at $4{ }^{\circ} \mathrm{C}$ and in $6 \% \mathrm{NaCl}$ and gluconate assimilation (Table 1). However, Ivanova et al. (2004) reported that DNA relatedness values were only $45-52 \%$ between S. affinis ATCC BAA- $642^{\mathrm{T}}$ and S. colwelliana ATCC $39565^{\mathrm{T}}$. The gyrB and $16 \mathrm{~S}$ rRNA gene sequence analyses and DNA-DNA hybridization newly performed in this study show no evidence to separate the two species genetically. Based on these results, S. affinis ATCC BAA- $642^{\mathrm{T}}$ and S. colwelliana ATCC $39565^{\mathrm{T}}$ received from the ATCC in March 2005 should be considered members of the same species.

Based on the findings of the polyphasic taxonomic study, it was determined that some of the strains isolated from marine fish from the Danish Baltic Sea represent two novel species within the genus Shewanella, Shewanella glacialipiscicola 


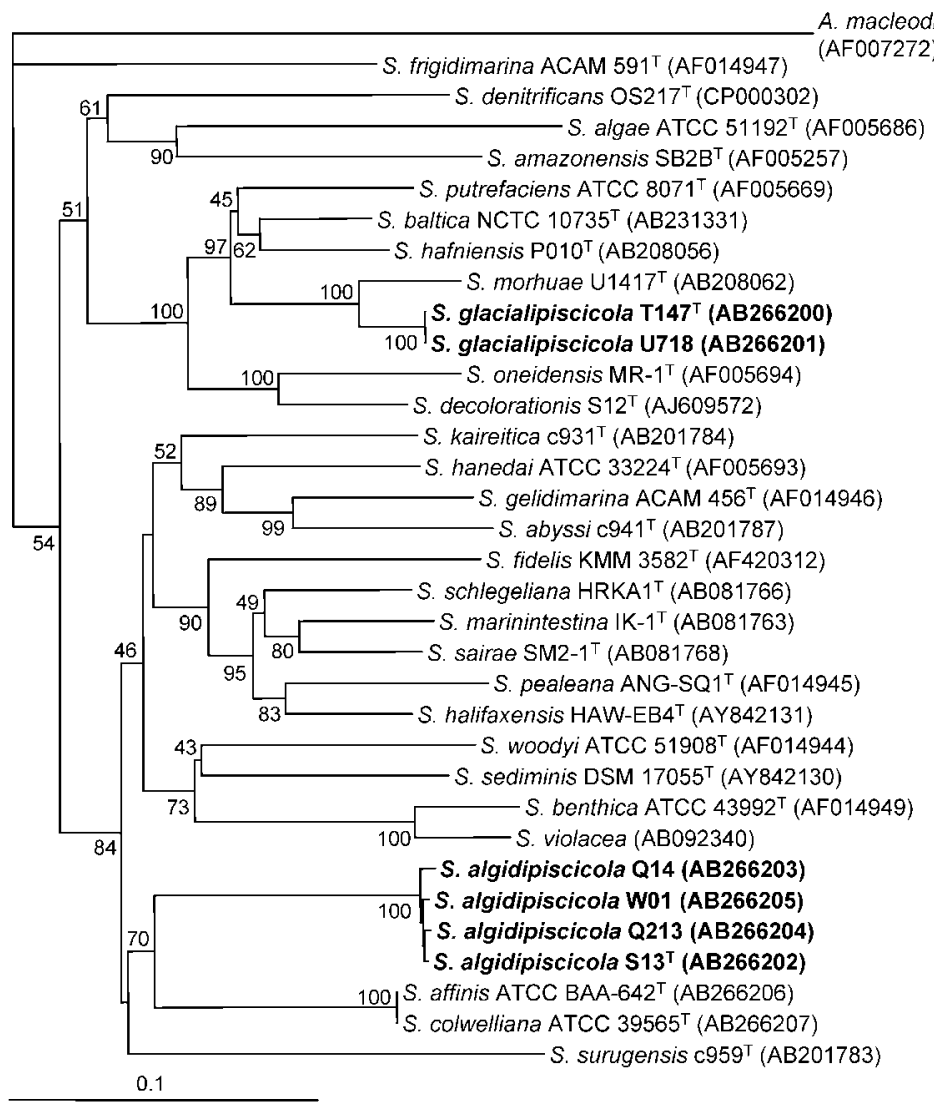

Fig. 2. Phylogenetic tree of the genus Shewanella based on gyrB gene sequences. The tree was constructed using the neighbour-joining method and genetic distances were computed by Kimura's model. The scale bar indicates a genetic distance of 0.1 . Numbers at nodes indicate percentages of occurrence in 1000 bootstrapped trees; only values greater than $40 \%$ are shown. Alteromonas macleodii ATCC $27126^{\top}$ was included as an outgroup. GenBank accession numbers are given in parentheses.

sp. nov. (represented by strain $\mathrm{T} 147^{\mathrm{T}}$ ) and Shewanella algidipiscicola sp. nov. (represented by strain $\mathrm{S}_{13}{ }^{\mathrm{T}}$ ). In addition, Shewanella affinis Ivanova et al. 2004 should be considered as a later heterotypic synonym of Shewanella colwelliana (Weiner et al. 1988) Coyne et al. 1990.

\section{Description of Shewanella glacialipiscicola sp. nov.}

Shewanella glacialipiscicola (gla'ci.a.li.pis'ci.co'la. L. adj. glacialis icy; L. n. piscis fish; L. suff. -cola dweller; N.L. n. glacialipiscicola iced fish dweller).

Mesophilic, aerobic and chemoheterotrophic. Cells are Gram-negative rods, $0.5-0.7 \mu \mathrm{m}$ in diameter and $1.0-1.2 \mu \mathrm{m}$ long, motile by means of polar flagella. None of the strains are capable of growing at concentrations of $6 \%$ $(\mathrm{w} / \mathrm{v}) \mathrm{NaCl}$. The temperature range for growth is $4-30{ }^{\circ} \mathrm{C}$, with $25^{\circ} \mathrm{C}$ being optimal. Growth does not occur at temperatures above $37^{\circ} \mathrm{C}$. Colonies are round, undulate, white-dull and non-luminescent and have irregular margins on marine agar plates incubated at $25^{\circ} \mathrm{C}$ for $24 \mathrm{~h}$. Cells are positive for oxidase and catalase reactions. They are unable to ferment glucose but reduce TMAO and produce $\mathrm{H}_{2} \mathrm{~S}$. Cells hydrolyse gelatin and aesculin, reduce nitrate and are positive for the production of DNase and ornithine decarboxylase, but do not produce acetoin, arginine dihydrolase, indole, urease or $\beta$-galactosidase. Cells utilize lactate, gluconate, $\mathrm{N}$-acetylglucosamine and malate readily as energy sources.
D-Glucose, citrate, sucrose, mannose, mannitol, adipic acid and phenylacetate are not utilized as sole carbon sources, but more than half of the strains tested assimilate arabinose. Cells do not grow on minimal media, indicating the presence of a required growth factor. The DNA G $+\mathrm{C}$ content is $44 \mathrm{~mol} \%$.

The type strain is $\mathrm{T} 147^{\mathrm{T}}\left(=\mathrm{LMG} 23744^{\mathrm{T}}=\mathrm{NBRC} 102030^{\mathrm{T}}\right.$ ), isolated from cod from Danish waters of the Baltic Sea. Strain U718 ( = LMG 23745 = NBRC 102031) is a reference strain.

\section{Description of Shewanella algidipiscicola sp. nov.}

Shewanella algidipiscicola (al.gi' di.pis' ci.co'la. L. adj. algidus cold; L. n. piscis fish; L. suff. -cola dweller; N.L. n. algidipiscicola cold-fish dweller).

Mesophilic, aerobic and chemoheterotrophic. Cells are Gram-negative rods, $0.5-0.7 \mu \mathrm{m}$ in diameter and $1.0-1.2 \mu \mathrm{m}$ long, motile by means of polar flagella. Capable of growing at $6 \%(\mathrm{w} / \mathrm{v}) \mathrm{NaCl}$. The temperature range for growth is $4-37^{\circ} \mathrm{C}$, with $25^{\circ} \mathrm{C}$ being optimal. Growth does not occur at temperatures above $42^{\circ} \mathrm{C}$. Colonies are round, undulate, white-dull and non-luminescent and have irregular margins on TSA plates incubated at $25^{\circ} \mathrm{C}$ for $24 \mathrm{~h}$. Cells are positive for oxidase and catalase reactions. They are unable to ferment glucose or hydrolyse gelatin, but reduce TMAO and produce $\mathrm{H}_{2} \mathrm{~S}$. Cells reduce nitrate and are positive for the production of DNase and 
ornithine decarboxylase, but do not produce acetoin, arginine dihydrolase, indole, urease or $\beta$-galactosidase. Cells are unable to use most of the carbon substrates tested, although lactate, $\mathrm{N}$-acetylglucosamine and malate are readily utilized as energy sources. D-Glucose, gluconate, maltose, citrate, sucrose, mannose, mannitol, adipic acid and phenylacetate are not utilized as sole carbon sources, but several strains assimilate arabinose and capric acid. Cells do not grow on minimal media, indicating the presence of a required growth factor. The DNA G+C content is $47 \mathrm{~mol} \%$.

The type strain is $\mathrm{S} 13^{\mathrm{T}}\left(=\mathrm{LMG} 23746^{\mathrm{T}}=\right.$ NBRC $\left.102032^{\mathrm{T}}\right)$, isolated from plaice from Danish waters of the Baltic Sea. Strains Q14 (=LMG $23477=$ NBRC 102033), Q213 and W01 are reference strains.

\section{Acknowledgements}

The technical assistance of Anemone Bundvad is acknowledged. Shariff Osman is acknowledged for critically reviewing the manuscript.

\section{References}

Altschul, S. F., Gish, W., Miller, W., Myers, E. W. \& Lipman, D. J. (1990). Basic local alignment search tool. J Mol Biol 215, 403-410.

Ezaki, T., Hashimoto, Y. \& Yabuuchi, E. (1989). Fluorometric deoxyribonucleic acid-deoxyribonucleic acid hybridization in microdilution wells as an alternative to membrane filter hybridization in which radioisotopes are used to determine genetic relatedness among bacterial strains. Int J Syst Bacteriol 39, 224-229.

Frazier, W. C. (1926). A method for the detection of changes in gelatin due to bacteria. J Infect Dis 39, 302-306.

Gram, L. \& Huss, H. H. (1996). Microbiological spoilage of fish and fish products. Int J Food Microbiol 33, 121-137.

Gram, L., Trolle, G. \& Huss, H. H. (1987). Detection of specific spoilage bacteria from fish stored at low $\left(0{ }^{\circ} \mathrm{C}\right)$ and high $\left(20^{\circ} \mathrm{C}\right)$ temperatures. Int J Food Microbiol 4, 65-72.

Gregerson, T. (1978). Rapid method for distinction of Gramnegative from Gram-positive bacteria. Eur J Appl Microbiol Biotechnol 5, 123-127.

Ivanova, E. P., Nedashkovskaya, O. I., Sawabe, T., Zhukova, N. V., Frolova, G. M., Nicolau, D. V., Mikhailov, V. V. \& Bowman, J. P. (2004). Shewanella affinis sp. nov., isolated from marine invertebrates. Int J Syst Evol Microbiol 54, 1089-1093.

Johnson, J. L. (1981). Genetic characterization. In Manual of Methods for General Bacteriology, pp. 450-472. Edited by P. Gerhardt, R. G. E. Murray, R. N. Costilow, E. W. Nester, W. A. Wood, N. R. Krieg \& G. B. Phillips. Washington, DC: American Society for Microbiology.

Kimura, M. (1980). A simple method for estimating evolutionary rates of base substitutions through comparative studies of nucleotide sequences. J Mol Evol 16, 111-120.

Okuzumi, M., Okuda, S. \& Awano, M. (1981). Isolation of psychrophilic and halophilic histamine-forming bacteria from Scomber japonicus. Bull Jpn Soc Sci Fish 47, 1591-1598.

Saitou, N. \& Nei, M. (1987). The neighbor-joining method: a new method for reconstructing phylogenetic trees. Mol Biol Evol 4, 406-425.

Sambrook, J., Fritsch, E. L. \& Maniatis, T. (1989). Molecular Cloning: a Laboratory Manual, 2nd edn. Cold Spring Harbor, NY: Cold Spring Harbor Laboratory.
Satomi, M., Kimura, B., Mizoi, M., Sato, T. \& Fujii, T. (1997). Tetragenococcus muriaticus sp. nov., a new moderately halophilic lactic acid bacterium isolated from fermented squid liver sauce. Int J Syst Bacteriol 47, 832-836.

Satomi, M., Oikawa, H. \& Yano, Y. (2003). Shewanella marinintestina sp. nov., Shewanella schlegeliana sp. nov. and Shewanella sairae sp. nov., novel eicosapentaenoic-acid-producing marine bacteria isolated from sea-animal intestines. Int J Syst Evol Microbiol 53, 491-499.

Satomi, M., Vogel, B. F., Gram, L. \& Venkateswaran, K. (2006). Shewanella hafniensis sp. nov. and Shewanella morhuae sp. nov., isolated from marine fish of the Baltic Sea. Int J Syst Evol Microbiol 56, 243-249.

Shewan, J. M., Hoggs, G. \& Hodgkiss, W. (1960). A determinative scheme for the identification of certain genera of gram-negative bacteria, with special reference to the Pseudomonadaceae. J Appl Bacteriol 23, 379-390.

Stackebrandt, E. \& Goebel, B. M. (1994). Taxonomic note: a place for DNA-DNA reassociation and $16 \mathrm{~S}$ rRNA sequence analysis in the present species definition in bacteriology. Int J Syst Bacteriol 44, 846-849.

Stenstrom, I. M. \& Molin, G. (1990). Classification of the spoilage flora of fish, with special reference to Shewanella putrefaciens. J Appl Bacteriol 68, 601-618.

Thompson, J. D., Higgins, D. G. \& Gibson, T. J. (1994). ClUSTAL W: improving the sensitivity of progressive multiple sequence alignment through sequence weighting, position-specific gap penalties and weight matrix choice. Nucleic Acids Res 22, 4673-4680.

Venkateswaran, K., Moser, D. P., Dollhopf, M. E., Lies, D. P., Saffarini, D. A., MacGregor, B. J., Ringelberg, D. B., White, D. C., Nishijima, M. \& other authors (1999). Polyphasic taxonomy of the genus Shewanella and description of Shewanella oneidensis sp. nov. Int J Syst Bacteriol 49, 705-724.

Vogel, B. F., Jorgensen, K., Christensen, H., Olsen, J. E. \& Gram, L. (1997). Differentiation of Shewanella putrefaciens and Shewanella alga on the basis of whole-cell protein profiles, ribotyping, phenotypic characterization, and 16S rRNA gene sequence analysis. Appl Environ Microbiol 63, 2189-2199.

Vogel, B. F., Venkateswaran, K., Satomi, M. \& Gram, L. (2005). Identification of Shewanella baltica as the most important $\mathrm{H}_{2} \mathrm{~S}$ producing species during iced storage of Danish marine fish. Appl Environ Microbiol 71, 6689-6697.

Wayne, L. G., Brenner, D. J., Colwell, R. R., Grimont, P. A. D., Kandler, O., Krichevsky, M. I., Moore, L. H., Moore, W. E. C., Murray, R. G. E. \& other authors (1987). International Committee on Systematic Bacteriology. Report of the ad hoc committee on reconciliation of approaches to bacterial systematics. Int J Syst Bacteriol 37, 463-464.

Weiner, R. M., Coyne, V. E., Brayton, P., West, P. \& Raiken, S. F. (1988). Alteromonas colwelliana sp. nov., an isolate from oyster habitats. Int J Syst Bacteriol 38, 240-244.

Weisburg, W. G., Barns, S. M., Pelletier, D. A. \& Lane, D. J. (1991). $16 \mathrm{~S}$ ribosomal DNA amplification for phylogenetic study. J Bacteriol 173, 697-703.

Yamamoto, S. \& Harayama, S. (1995). PCR amplification and direct sequencing of $g y r B$ genes with universal primers and their application to the detection and taxonomic analysis of Pseudomonas putida strains. Appl Environ Microbiol 61, 1104-1109.

Ziemke, F., Brettar, I. \& Höfle, M. G. (1997). Stability and diversity of the genetic structure of a Shewanella putrefaciens population in the water column of the central Baltic. Aquat Microb Ecol 13, 63-74.

Ziemke, F., Höfle, M. G., Lalucat, J. \& Rosselló-Mora, R. (1998). Reclassification of Shewanella putrefaciens Owen's genomic group II as Shewanella baltica sp. nov. Int J Syst Bacteriol 48, 179-186. 